\title{
Supplementary Materials: Furan carboxamides as model compounds to study the competition between two modes of indirect photochemistry
}

Rachele Ossola, Markus Schmitt, Paul R. Erickson and Kristopher McNeill

\section{Contents}

S1 Overview of dual-mode reactivity molecules $\ldots \ldots \ldots \ldots \ldots \ldots$. . . . . . . . .

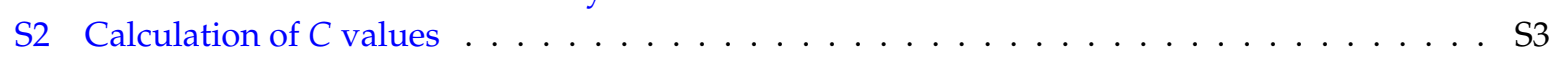

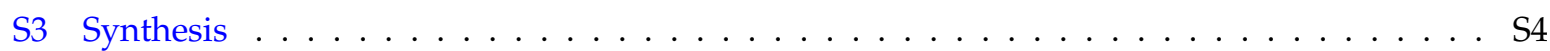

S3.1 Chemicals . . . . . . . . . . . . . . . . . . . . S4

S3.2 General procedure (readapted from Pelltier et al.[1]) . . . . . . . . . . . . . . S4

S4 UVA lamp spectrum and model sensitizers UV-Vis absorption spectra . . . . . . . . . . . . . . S6

S5 Furanilides UV-Vis absorption spectra $\ldots \ldots \ldots \ldots \ldots \ldots \ldots \ldots \ldots$

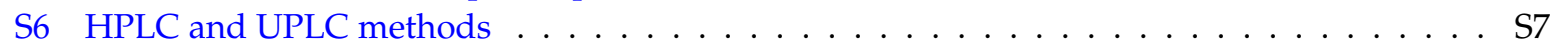

S7 Supplementary graphs on data analysis $\ldots \ldots \ldots \ldots \ldots \ldots \ldots \ldots \ldots$

S8 Fenfuram degradation rates comparison in different experimental conditions . . . . . . . . . S9

S9 Degradation rate comparison among different furanilides (Figure $2 \mathrm{~B}$ ) $\ldots \ldots \ldots \ldots$. . . . S10

S9.1 Steady-state experiments . . . . . . . . . . . . . . . . . . S10

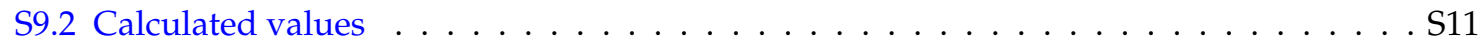

S10 Hammett plot . . . . . . . . . . . . . . . . . . . . . . . S13

S11 Supplementary transient absorption spectra . . . . . . . . . . . . . . . . . S14

S12 Antioxidant quenching experiments . . . . . . . . . . . . . . . . S17

S13 Details of the calculated FFA-normalized 1-(OMe $)_{3}$ degradation rate constants . . . . . . . S18

S14 Supplementary data on the indirect degradation of 1-OMe . . . . . . . . . . . . . S20

S15 Summary of the variables used in the equations . . . . . . . . . . . . . . S21 


\section{S1. Overview of dual-mode reactivity molecules}

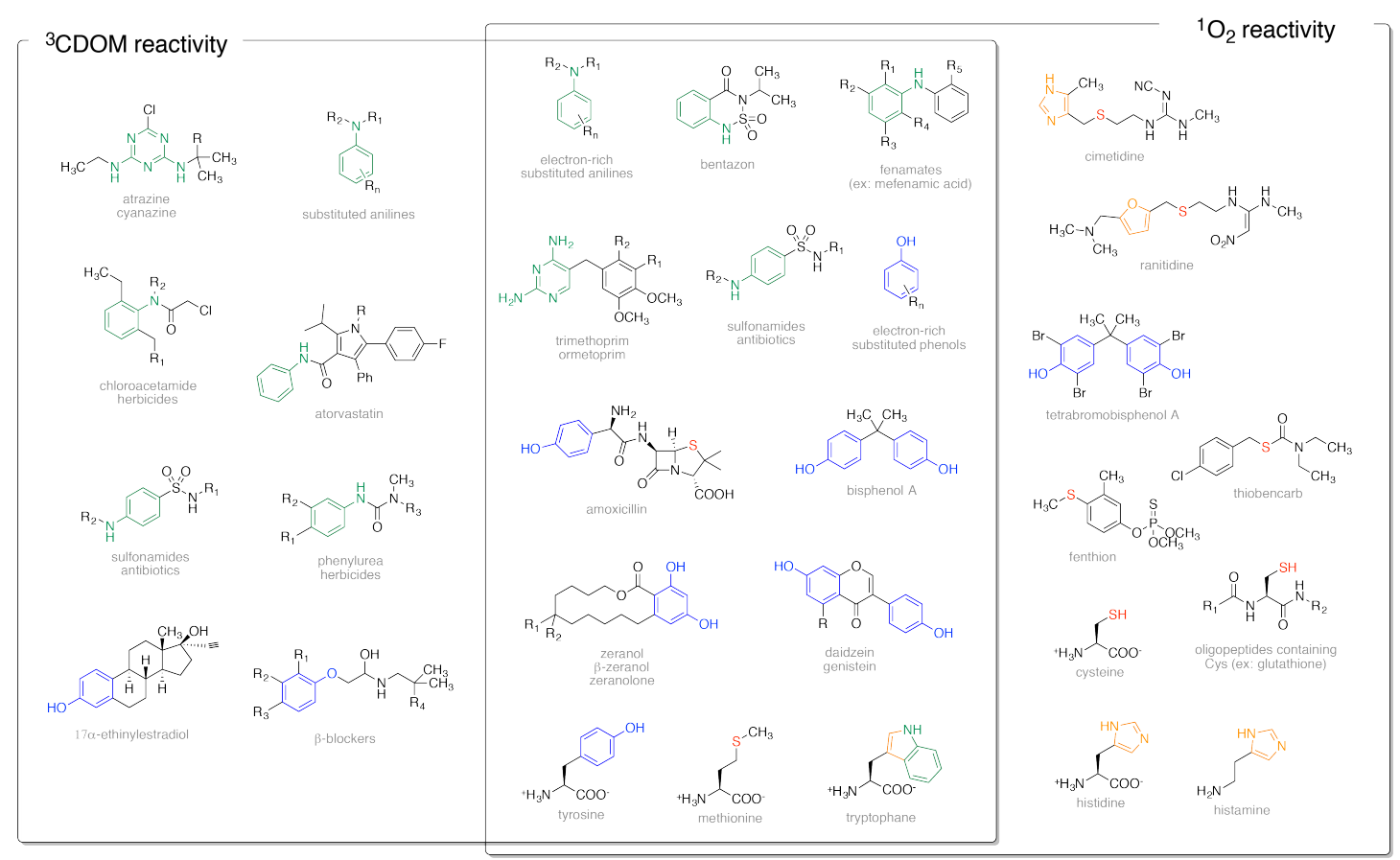

Figure S1. Overview of dual-mode reactivity molecules compiled from McNeill and Canonica $\left({ }^{3} \mathrm{CDOM}^{*}\right.$-reactive compounds)[2], Latch $\left({ }^{1} \mathrm{O}_{2}\right.$-reactive compounds)[3] and Lundeen et al. (amino acids)[4]. Additional information for selected compound classes (beyond the ones compiled in the reviews) can be found in Davis et al. (fenamates)[5], Chu et al. (cysteine-containing oligopeptides)[6] and Remucal (general review on pesticides photodegradation)[7]. Colour-code: green = aromatic amine $/$ amide; blue $=$ phenol; red $=$ thiol/thioether; orange $=$ heterocycle. As a general rule, electron-rich heterocycles are expected to react with ${ }^{1} \mathrm{O}_{2}$, while the other highlighted functional groups can react with both reactive species, depending on their electron density and on the surrounding functional groups. Note that this overview is not exhaustive. 


\section{S2. Calculation of $C$ values}

According to McNeill and Canonica, the ratio of singlet oxygen and ${ }^{3} \mathrm{CDOM}^{*}$ steady-state concentrations can be expressed as following.[2]

$$
\frac{\left[{ }^{1} \mathrm{O}_{2}\right]_{s s}}{\left[{ }^{3} \mathrm{CDOM}^{*}\right]_{s s}}=\frac{k_{\mathrm{O}_{2}}\left[\mathrm{O}_{2}\right] f_{\Delta}}{k_{d}^{\Delta}},
$$

where $k_{\mathrm{O}_{2}}$ is the bimolecular rate constant for the quenching of ${ }^{3} \mathrm{CDOM}^{*}$ with ground state oxygen, $f_{\Delta}$ is the fraction of oxygen-dependent triplet quenching that produces singlet oxygen, and $k_{d}^{\Delta}$ is the rate constant for the relaxation of singlet oxygen to the ground state. By defining $C$ as

$$
C=\frac{k_{\mathrm{O}_{2}}\left[\mathrm{O}_{2}\right]}{k_{d}^{\Delta}}
$$

one can rearrange equation $\mathrm{S} 1$ to obtain the following expression (equation 3 in the main text).

$$
\frac{\left[{ }^{1} \mathrm{O}_{2}\right]_{s s}}{\left[{ }^{3} \mathrm{CDOM}^{*}\right]_{s s}}=C f_{\Delta}
$$

In their review, McNeill and Canonica estimated $C \approx 2$ at $25^{\circ} \mathrm{C}$ using $k_{\mathrm{O}_{2}}=2 \times 10^{9} \mathrm{~L} \mathrm{~mol}^{-1} \mathrm{~s}^{-1}$, a typical value for well-defined sensitizers, $\left[\mathrm{O}_{2}\right]=258 \mu \mathrm{mol} \mathrm{L}^{-1}$ and $k_{d}^{\Delta}=2.5 \times 10^{5} \mathrm{~s}^{-1}$. We recalculated $C$ using the most recent $k_{\mathrm{O}_{2}}$ values by Erickson, Moor et al.[8] and $k_{d}^{\Delta}=2.76 \times 10^{5} \mathrm{~s}^{-1}$ from Appiani, Ossola et al.[9]. Assuming that $k_{d}^{\Delta}$ and $k_{\mathrm{O}_{2}}$ have a negligible variation in the temperature range 20-35 ${ }^{\circ} \mathrm{C}$, we estimated $C$ for Suwannee River Fulvic Acid (SRFA), perinaphthenone (PN) and lumichrome (LC) at $20^{\circ}, 25^{\circ}, 30^{\circ}$ and $35^{\circ} \mathrm{C}$. The results are listed in Table S1.

Table S1. Parameters and results of the calculation of the constant $C$ according to equation S2. The rate constants are from Erickson, Moor et al. $\left(k_{\mathrm{O}_{2}}\right.$ for PN and SRFA)[8], Sikorski et al. $\left(k_{\mathrm{O}_{2}}\right.$ for LC at pH 6)[10] and Appiani, Ossola et al. $\left(k_{d}^{\Delta}\right)$ [9]. The values in bold are relative to the experimental conditions of the steady-state experiments, i.e. $26^{\circ} \mathrm{C}$ for PN and LC (4 lamps) and $34^{\circ} \mathrm{C}$ for SRFA (10 lamps).

\begin{tabular}{lcccc}
\hline Sensitizer & $k_{\mathrm{O}_{2}}\left(\mathrm{~L} \mathrm{~mol}^{-1} \mathrm{~s}^{-1}\right)$ & $k_{d}^{\Delta}\left(\mathrm{s}^{-1}\right)$ & {$\left[\mathrm{O}_{2}\right]\left(\mu \mathrm{mol} \mathrm{L}^{-1}\right)$} & $\mathrm{C}$ \\
\hline$T=20^{\circ} \mathrm{C}$ & & & & \\
SRFA & $8.1 \times 10^{8}$ & $2.76 \times 10^{5}$ & 284 & 0.83 \\
PN & $1.9 \times 10^{9}$ & $2.76 \times 10^{5}$ & 284 & 1.96 \\
LC & $1.6 \times 10^{9}$ & $2.76 \times 10^{5}$ & 284 & 1.64 \\
& & & & \\
$T=25^{\circ} \mathrm{C}$ & & & & \\
SRFA & $8.1 \times 10^{8}$ & $2.76 \times 10^{5}$ & 256 & 0.75 \\
PN & $1.9 \times 10^{9}$ & $2.76 \times 10^{5}$ & 256 & $\mathbf{1 . 7 6}$ \\
LC & $1.6 \times 10^{9}$ & $2.76 \times 10^{5}$ & 256 & $\mathbf{1 . 4 8}$ \\
& & & & \\
$T=30^{\circ} \mathrm{C}$ & & & & \\
SRFA & $8.1 \times 10^{8}$ & $2.76 \times 10^{5}$ & 236 & 0.69 \\
PN & $1.9 \times 10^{9}$ & $2.76 \times 10^{5}$ & 236 & 1.62 \\
LC & $1.6 \times 10^{9}$ & $2.76 \times 10^{5}$ & 236 & 1.37 \\
& & & & \\
$T=35^{\circ} \mathrm{C}$ & & & & \\
SRFA & $8.1 \times 10^{8}$ & $2.76 \times 10^{5}$ & 217 & $\mathbf{0 . 6 4}$ \\
PN & $1.9 \times 10^{9}$ & $2.76 \times 10^{5}$ & 217 & 1.49 \\
LC & $1.6 \times 10^{9}$ & $2.76 \times 10^{5}$ & 217 & 1.26 \\
\hline
\end{tabular}




\section{S3. Synthesis}

\section{S3.1. Chemicals}

Aniline, $p$-toluidine, $p$-anisidine, $N, N$-diethyl- $p$-phenylenediamine and methyl 4 -aminobenzoate were purchased from Sigma Aldrich. 3,4,5-Trimethoxyaniline and 3-furoylchloride were obtained from Fluorochem. 2-Methyl-3-furoyl chloride was bought from Alfa Aesar, and 2,5-dimethyl-3-furoyl chloride was obtained from Maybridge. All compounds were used as received. Flash chromatography was performed with Silia Flash P60 230-400 mesh. Hexane and ethyl acetate were from LiChrosolv, while dichloromethane $\left(\mathrm{CH}_{2} \mathrm{Cl}_{2}\right)$ was purchased from Fisher Scientific (UK). $\mathrm{CH}_{2} \mathrm{Cl}_{2}$ was dried prior to use with activated molecular sieves (Acros Organics, 4A 8-12 mesh). ${ }^{1} \mathrm{H}-\mathrm{NMR}$ spectra were recorded with a Bruker Avance III $400 \mathrm{MHz}$ NMR instrument and were analysed with MestreNova (Version 10.0).

\section{S3.2. General procedure (readapted from Pelltier et al.[1])}<smiles>Cc1cocc1C(=O)Cl</smiles><smiles>[R]c1ccc(N)cc1</smiles><smiles>CCNCCN(C)CC</smiles><smiles>Cc1cocc1C(=O)Nc1ccc(P)cc1</smiles>

The aromatic amine (1.1 eq) was dissolved in $\mathrm{CH}_{2} \mathrm{Cl}_{2}$, triethylamine $\left(\mathrm{NEt}_{3}, 1.1 \mathrm{eq}\right)$ was spiked in and the reaction mixture was cooled to $0{ }^{\circ} \mathrm{C}$. The furoylchloride $(1.0 \mathrm{eq})$ was then added dropwise. The reaction was allowed to warm to room temperature and it was stirred overnight. The entire procedure was performed in a water-free 2-neck bottom flask kept under nitrogen. The reaction was quenched with saturated aqueous $\mathrm{Na}_{2} \mathrm{CO}_{3}\left(\mathrm{pH}\right.$ 11-12), it was diluted with $\mathrm{CH}_{2} \mathrm{Cl}_{2}$, and the organic phases were separated. The aqueous phase was extracted twice with $\mathrm{CH}_{2} \mathrm{Cl}_{2}$, the combined organic layers were washed with aqueous $\mathrm{HCl}(1 \mathrm{~N})$, dried over $\mathrm{Na}_{2} \mathrm{SO}_{4}$ and filtered. The solvent was removed at reduced pressure with a rotary evaporator to give a crude reaction product that was recrystallized from hexane:ethyl acetate 1:1. For $\mathbf{2}$ and $\mathbf{1 - N M e}$, flash chromatography (silica, eluent hexane:ethyl acetate 1:1) was performed prior to recrystallization. In some cases, the products were not soluble in hexane:ethyl acetate 1:1 and were either only washed with this eluent mixtures or used without further purification.

Furan-3-carboxanilide (0) Furan-3-carboxanilide was synthesitzed from aniline (160 $\mu \mathrm{L}, 1.76$ mmol), triethylamine $(250 \mu \mathrm{L}, 1.79 \mathrm{mmol})$ and 3-furoyl chloride $(160 \mu \mathrm{L}, 1.62 \mathrm{mmol})$ in $9 \mathrm{~mL}$ of dry $\mathrm{CH}_{2} \mathrm{Cl}_{2}$. Crystallization of the crude reaction product (303 $\mathrm{mg}$, quantitative) gave colorless needle-like crystals $(235 \mathrm{mg}, 78 \%) .{ }^{1} \mathrm{H}$ NMR $\left(400 \mathrm{MHz}, \mathrm{CDCl}_{3}\right): \delta 8.06$ (br. s, $\left.1 \mathrm{H}\right), 7.65$ (d(d), J=7.5, $2 \mathrm{H}), 7.52(\mathrm{~d}(\mathrm{~d}), J=1.8,0.5 \mathrm{~Hz}, 1 \mathrm{H}), 7.37(\mathrm{t}, J=7.5 \mathrm{~Hz}, 2 \mathrm{H}), 7.25(\mathrm{~d}(\mathrm{~d}), J=3.5,0.5 \mathrm{~Hz}, 1 \mathrm{H}), 7.15(\mathrm{t}, J=7.5$ $\mathrm{Hz}, 1 \mathrm{H}), 6.75(\mathrm{dd}, J=3.5,1.8 \mathrm{~Hz}, 1 \mathrm{H})$. TLC (hexane:ethyl acetate 1:1) $R_{f}=0.60$.

Methyl $p$-(2-methyl-3-furoylamino)benzoate $\left(1-\mathrm{CO}_{2} \mathrm{Me}\right)$ This compound was synthesized from methyl 4-aminobenzoate $(257.50 \mathrm{mg}, 1.70 \mathrm{mmol})$, triethylamine $(240 \mu \mathrm{L}, 1.72 \mathrm{mmol})$ and 2-methyl-3-furoyl chloride ( $60 \mu \mathrm{L}, 0.52 \mathrm{mmol})$ in $9 \mathrm{~mL}$ of dry $\mathrm{CH}_{2} \mathrm{Cl}_{2}$. The crude reaction product (275 mg, quantitative) was washed with hexane:ethyl acetate 1:1, the soluble phase was discarded and the leftover solvent was removed at reduced pressure. The product was isolated as milky white powder $(149.8 \mathrm{mg}, 55 \%) .{ }^{1} \mathrm{H} \mathrm{NMR}\left(400 \mathrm{MHz}, \mathrm{CDCl}_{3}\right): \delta 8.04(\mathrm{~d}, \mathrm{~J}=8.8 \mathrm{~Hz}, 2 \mathrm{H}), 7.68(\mathrm{~d}, \mathrm{~J}=8.8 \mathrm{~Hz}$, 2H), 7.48 (br. s, 1H), $7.33(\mathrm{~d}, \mathrm{~J}=2.0 \mathrm{~Hz}, 1 \mathrm{H}), 6.54(\mathrm{~d}, \mathrm{~J}=2.0 \mathrm{~Hz}, 1 \mathrm{H}), 3.91(\mathrm{~s}, 3 \mathrm{H}), 2.65(\mathrm{~s}, 3 \mathrm{H})$. TLC (hexane:ethyl acetate 1:1) $R_{f}=0.63$.

2-methylfuran-3-( $N$ - $p$-tolyl)carboxamide (1-Me) This compound was synthesized from $p$-toluidine (192.9 mg, $1.80 \mathrm{mmol})$, triethylamine $(250 \mu \mathrm{L}, 1.79 \mathrm{mmol})$ and 2-methyl-3-furoyl chloride 
(180 $\mu \mathrm{L}, 1.57 \mathrm{mmol}$ ) in $9 \mathrm{~mL}$ of dry $\mathrm{CH}_{2} \mathrm{Cl}_{2}$. The product was obtained as an orange opaque oil (350 $\mathrm{mg}$, quantitative), and it was used without further purifications. ${ }^{1} \mathrm{H}$ NMR $\left(400 \mathrm{MHz}\right.$, Methanol $\left.-d_{4}\right)$ : $\delta 7.48(\mathrm{~d}, \mathrm{~J}=8.4 \mathrm{~Hz}, 2 \mathrm{H}), 7.40(\mathrm{~d}, \mathrm{~J}=2.0 \mathrm{~Hz}, 1 \mathrm{H}), 7.15(\mathrm{~d}, \mathrm{~J}=8.4 \mathrm{~Hz}, 2 \mathrm{H}), 6.87(\mathrm{~d}, \mathrm{~J}=2.0 \mathrm{~Hz}, 1 \mathrm{H}), 2.56$ (s, 3H), $2.31(\mathrm{~s}, 3 \mathrm{H})$. TLC (hexane:ethyl acetate 1:1) $R_{f}=0.75$.

2-methylfuran-3-( $N$ - $p$-anisyl)carboxamide (1-OMe) This compound was synthesized from p-anisidine (205.7 mg $1.67 \mathrm{mmol})$, triethylamine $(230 \mu \mathrm{L}, 1.56 \mathrm{mmol})$ and 2-methyl-3-furoyl chloride (170 $\mu \mathrm{L}, 1.47 \mathrm{mmol})$ in $8.5 \mathrm{~mL}$ of dry $\mathrm{CH}_{2} \mathrm{Cl}_{2}$. Crystallization of the crude reaction product $(350 \mathrm{mg}$, quantitative) gave violet transparent platelets $\left(253 \mathrm{mg}, 72 \%\right.$, the brown solid was discarded). ${ }^{1} \mathrm{H}$ NMR $\left(400 \mathrm{MHz}, \mathrm{CDCl}_{3}\right): \delta 7.46(\mathrm{~d}, \mathrm{~J}=8.9 \mathrm{~Hz}, 2 \mathrm{H}), 7.30(\mathrm{~d}, \mathrm{~J}=1.9 \mathrm{~Hz}, 1 \mathrm{H}), 7.29$ (br. s, $\left.1 \mathrm{H}\right), 6.89$ (d, $\mathrm{J}=8.9 \mathrm{~Hz}, 2 \mathrm{H}), 6.52(\mathrm{~d}, \mathrm{~J}=1.9 \mathrm{~Hz}, 1 \mathrm{H}), 3.80(\mathrm{~s}, 3 \mathrm{H}), 2.63(\mathrm{~s}, 3 \mathrm{H})$. TLC (hexane:ethyl acetate 1:1) $R_{f}=0.65$.

2-methylfuran-3-(N-3,4,5-trimetoxyphenyl)carboxamide (1-(OMe $\left.)_{3}\right)$ This compound was synthesized from 3,4,5-trimethoxy aniline $(310.61 \mathrm{mg}, 1.70 \mathrm{mmol})$, triethylamine ( $240 \mu \mathrm{L}, 1.72 \mathrm{mmol})$ and 2-methyl-3-furoyl chloride $(180 \mu \mathrm{L}, 1.60 \mathrm{mmol})$ in $8.5 \mathrm{~mL}$ of dry $\mathrm{CH}_{2} \mathrm{Cl}_{2}$. The product was obtained as a pale yellow solid ( $428 \mathrm{mg}, 92 \%)$, and it was used without further purification. ${ }^{1} \mathrm{H} \mathrm{NMR}$ (400 MHz, CDCl $): \delta 7.31$ (s, 1H), 7.28 (br. s, $1 \mathrm{H}), 6.88(\mathrm{~s}, 2 \mathrm{H}), 6.53(\mathrm{~s}, 1 \mathrm{H}), 3.87(\mathrm{~s}, 6 \mathrm{H}), 3.83(\mathrm{~s}, 3 \mathrm{H})$, $2.64(\mathrm{~s}, 3 \mathrm{H})$. TLC (hexane:ethyl acetate 1:1) $R_{f}=0.28$.

2-methylfuran-3-(N-p-dimethylaminophenyl)carboxamide (1-NMe $)_{2}$ This compound was synthesized from 4-amino- $N, N$-dimethyl aniline $(245.28 \mathrm{mg}, 1.80 \mathrm{mmol})$, triethylamine $(250 \mu \mathrm{L}, 1.79$ mmol) and 2-methyl-3-furoyl chloride $(180 \mu \mathrm{L}, 1.57 \mathrm{mmol})$ in $9 \mathrm{~mL}$ of dry $\mathrm{CH}_{2} \mathrm{Cl}_{2}$. The reaction mixture was washed with saturated $\mathrm{Na}_{2} \mathrm{CO}_{3}$, the wine-red organic phases were anhydrified over $\mathrm{Na}_{2} \mathrm{SO}_{4}$ and filtered. No acidic workup was performed. The solvent was removed at reduced pressure and the brown solid ( $384 \mathrm{mg}$, quantitative) was purified by flash chromatography (eluent EtOAc:Hex 1:1, loaded as $\mathrm{CH}_{2} \mathrm{Cl}_{2}$ solution). 1- $\mathbf{N M e}_{2}$ was then crystallized to obtain pale beige small crystals (194 mg, overall yield 51\%). ${ }^{1} \mathrm{H}$ NMR $\left(400 \mathrm{MHz}, \mathrm{CDCl}_{3}\right): \delta 7.41(\mathrm{~d}, \mathrm{~J}=7.7 \mathrm{~Hz}, 2 \mathrm{H}), 7.29$ (s, 1H), 7.21 (br. s, 1H), 6.74 (br. s, 1H), 6.51 (s, 1H), 2.94 (br. s, 6H), 2.63 (s, 3H). TLC (hexane:ethyl acetate 1:1) $R_{f}=0.27$.

2,5-dimethylfuran-3-carboxanilide (FC, 2) This compound was synthesized from aniline (165 $\mu \mathrm{L}, 1.81 \mathrm{mmol})$, triethylamine $(250 \mu \mathrm{L}, 1.79 \mathrm{mmol})$ and 2,5-dimethyl-3-furoyl chloride (215 $\mu \mathrm{L}, 1.61$ mmol) in $9 \mathrm{~mL}$ of dry $\mathrm{CH}_{2} \mathrm{Cl}_{2}$. The crude reaction product $(271 \mathrm{mg}, 78 \%)$ was purified by flash chromatography and was further crystallized to obtain small beige crystals (148 $\mathrm{mg}$, overall yield $43 \%) .{ }^{1} \mathrm{H}$ NMR $\left(400 \mathrm{MHz}, \mathrm{CDCl}_{3}\right): \delta 7.56(\mathrm{~d}, J=8.4 \mathrm{~Hz}, 2 \mathrm{H}), 7.34(\mathrm{t}, J=8.4 \mathrm{~Hz}, 2 \mathrm{H}), 7.27$ (br. s), 7.12 (d, $J=8.4 \mathrm{~Hz}, 1 \mathrm{H}), 6.10(\mathrm{~s}, 1 \mathrm{H}), 2.59(\mathrm{~s}, 3 \mathrm{H}), 2.29(\mathrm{~s}, 3 \mathrm{H})$. TLC (hexane:ethyl acetate 1:1) $R_{f}=0.77$. 
S4. UVA lamp spectrum and model sensitizers UV-Vis absorption spectra
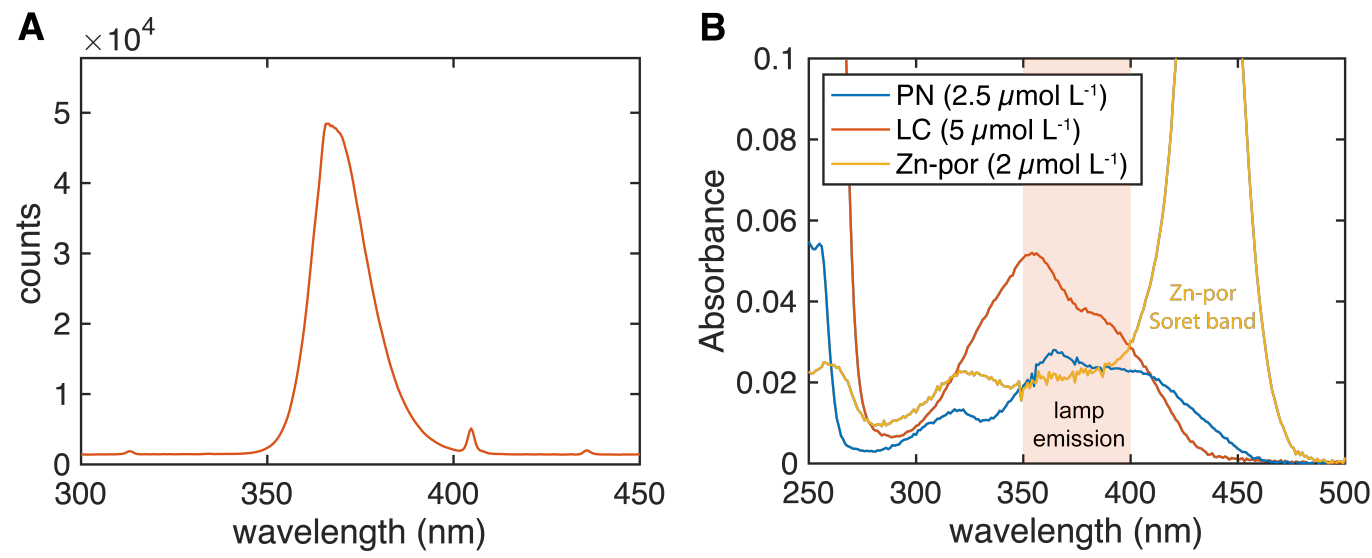

Figure S2. A Emission spectra of the UVA lamps recorded with a radiometer (Jaz, Ocean Optics) using 2 bulbs and 12 seconds integration time. The peak emission falls at $365 \mathrm{~nm}$. The borosilicate test tubes used are transparent above $320 \mathrm{~nm}$. B Absorption spectra of the three model sensitizers used in this study in $\mathrm{pH} 7$ phosphate buffer. At these sensitizers concentrations, we measured $\left[{ }^{1} \mathrm{O}_{2}\right]_{s s} \approx 5.3$ pmol $\mathrm{L}^{-1}(\mathrm{PN}), 7.5 \mathrm{pmol} \mathrm{L}{ }^{-1}$ (LC) and $3.8 \mathrm{pmol} \mathrm{L}^{-1}$ (Zn-por).

\section{S5. Furanilides UV-Vis absorption spectra}
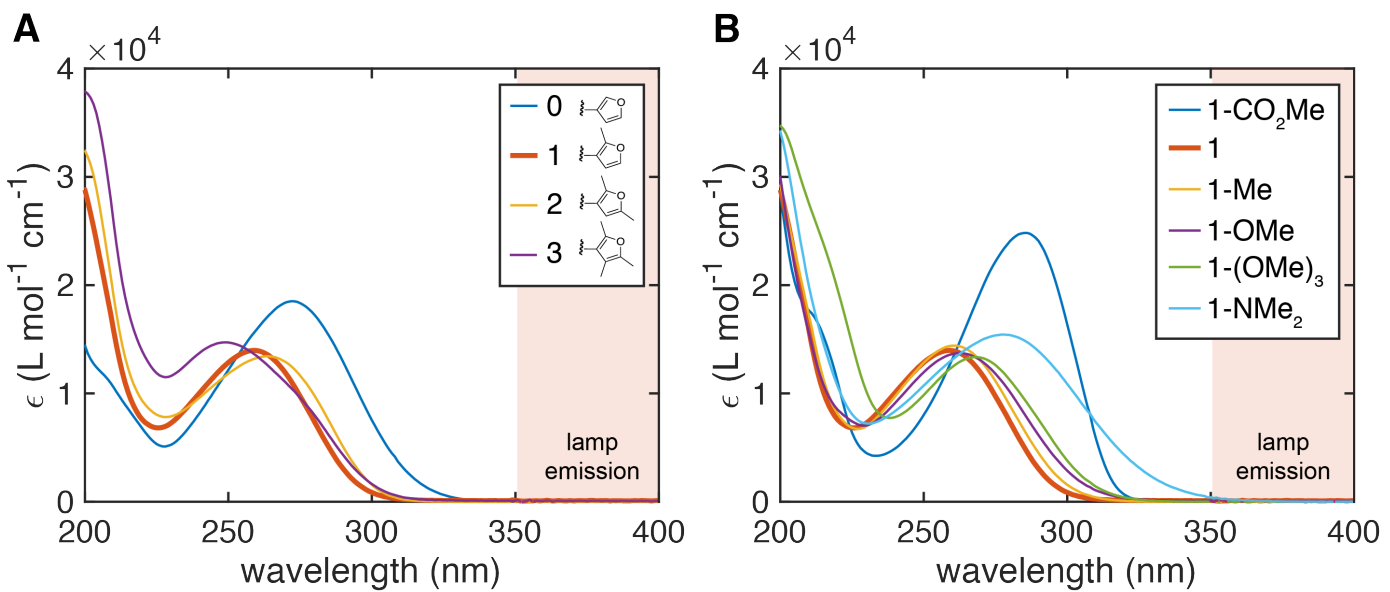

Figure S3. Absorption spectra of compounds of the furan (A) and the anilide (B) series in deionized water. In both graphs, the orange area indicates the UVA emission of the photoreactor (Figure S2A). 


\section{S6. HPLC and UPLC methods}

The nine furanilides and furfuryl alcohol were analyzed via HPLC (Dionex UltiMate 3000) or via UPLC (Waters ACQUITY UPLC system).

The Dionex UltiMate 3000 instrument was equipped with a C18 column (YMC ODS-AM, $250 \times$ $4.6 \mathrm{~mm}, 5 \mu \mathrm{m}$ ) thermostated at $28^{\circ} \mathrm{C}$, and a diode array detector. The analyses were performed in isocratic mode using as eluents a combination of (A) sodium acetate buffer $(\mathrm{pH} 6)+10 \% \mathrm{ACN}$ and (B) $100 \% \mathrm{ACN}$, with a flow rate of $1 \mathrm{~mL} \mathrm{~min}^{-1}$ and an injection volume of $10 \mu \mathrm{L}$. Specifically, 0 and fenfuram (1) were analyzed with an eluent ratio of 66:34 (A:B) and were detected at $258 \mathrm{~nm}$ (retention time $=8.6 \mathrm{~min}(\mathbf{0}) ; 13.8 \mathrm{~min}(\mathbf{1})) ; \mathbf{1}-\mathrm{CO}_{2} \mathbf{M e}, \mathbf{1}-\mathbf{M e}, \mathbf{1}-\mathbf{O M e}, \mathbf{1 -}(\mathbf{O M e})_{3}$ and $\mathbf{1 - N M \mathbf { N } _ { 2 }}$ were analyzed with an eluent ratio of 58:42 (A:B) and were detected at $258 \mathrm{~nm}$ (retention time $=10.9 \mathrm{~min}\left(\mathbf{1}-\mathrm{CO}_{2} \mathbf{M e}\right) ; 12.2$ $\left.\min (\mathbf{1 - M e}) ; 8.2 \mathrm{~min}(\mathbf{1 - O M e}) ; 7.4 \mathrm{~min}\left(\mathbf{1 -}(\mathbf{O M e})_{3}\right) ; 9.2 \mathrm{~min}\left(\mathbf{1}-\mathbf{N M e}_{2}\right)\right) ; \mathbf{2}$ and $\mathbf{3}$ were analyzed with an eluent ratio of 54:46 (A:B) and were detected at $258 \mathrm{~nm}$ (retention time = $10.1 \mathrm{~min}(2) ; 11.7 \mathrm{~min}(3)$ ). FFA was analyzed with a gradient method and was detected at $220 \mathrm{~nm}$ (retention time $=4.3 \mathrm{~min}$ ). The gradient was as following: $0-4 \mathrm{~min}, 70: 30(\mathrm{~A}: \mathrm{B}) ; 4-6 \mathrm{~min}$ from 70:30 to 30:70 (A:B); $6-10 \mathrm{~min}$ from 30:70 to 70:30 (A:B); 10 - 11 min, 70:30 (A:B).

The compounds 1-(OMe) $)_{3}$ and TMP were also analyzed with a different $\mathrm{C} 18$ column (Eclipse XDB-C18 $5 \mu \mathrm{m} 4.6 \times 150 \mathrm{~mm}$ ) installed on the same Dionex UltiMate 3000 instrument, with a flow

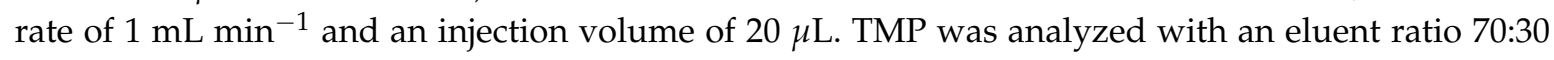
$(\mathrm{A}: \mathrm{B})$ and was detected using a fluorescence detector with excitation at $230 \mathrm{~nm}$ and emission at 325 $\mathrm{nm}$ (retention time $=2.8 \mathrm{~min})$, while 1-(OMe) ${ }_{3}$ was analyzed with an eluent ratio 50:50 (A:B) and was detected at $270 \mathrm{~nm}$ (retention time $=3.1 \mathrm{~min}$ ).

FFA was also quantified via UPLC. The instrument was equipped with a C18 column (Acquity, BEH130 C18, $1.7 \mu \mathrm{m} ; 2.1 \times 150 \mathrm{~mm}$ ), its guard column (C18 VanGuard pre-column, $130 \AA$, $1.7 \mu \mathrm{m} ; 2.1$ $\times 50 \mathrm{~mm}$ ) and a photodiod array detector. The analyses were performed using gradient elution with (A) sodium acetate buffer (pH 6) $+10 \% \mathrm{ACN}$ and (B) $100 \% \mathrm{ACN}$ as eluents, at $0.15 \mathrm{~mL} \mathrm{~min}{ }^{-1}$ flow rate, $5 \mu \mathrm{L}$ injection volume and detection at $219 \mathrm{~nm}$ (retention time $=3.2 \mathrm{~min}$ ). The gradient was as following: $0-1.5 \mathrm{~min}, 65: 35$ (A:B); $1.5-1.6 \mathrm{~min}$, from 65:35 to 20:80 (A:B); 1.6 - $3 \mathrm{~min}, 20: 80$ (A:B); 3.0 $-3.1 \mathrm{~min}$, from $20: 80$ to $65: 35$ (A:B); $3.1-7 \mathrm{~min}, 65: 35$ (A:B). 


\section{S7. Supplementary graphs on data analysis}

A
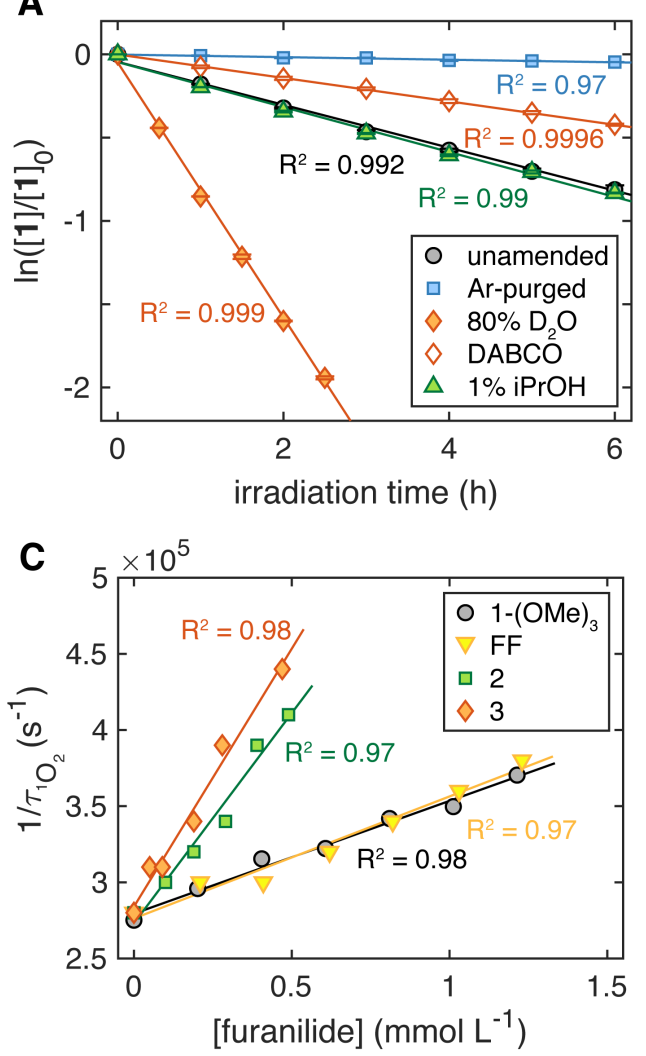
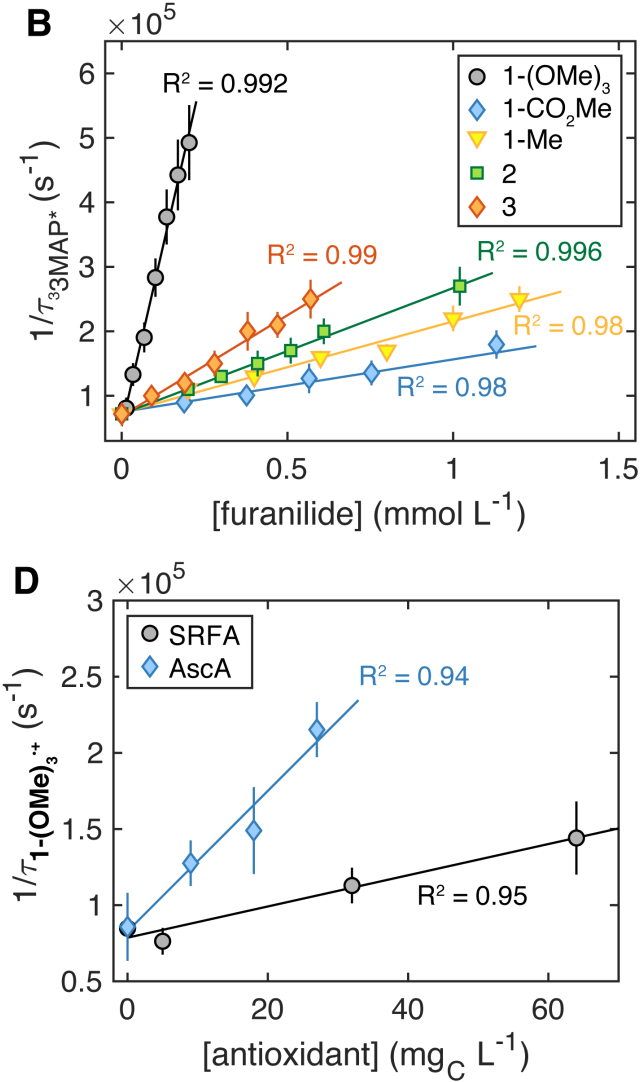

Figure S4. A Figure 2A (main text) is reproduced here with the experimental error bars indicating the spread in the experimental values (minimum and maximum values). The data reported in this figure were also used to estimate the average variation in the experimental results $(<2 \%)$. B Representative Stern-Volmer plots used to determine triplet quenching rate constants. Each symbol is the reciprocal of the ${ }^{3} 3 \mathrm{MAP}^{*}$ lifetime determined from the non-linear curve fit of the transient absorption spectrum signal at $395 \mathrm{~nm}$. The error bars indicate the standard error of the non-linear fit. The $R^{2}$ values of the linear regression line are also indicated. C Representative Stern-Volmer plots used to determine singlet oxygen quenching rate constants. Each symbol is the reciprocal of the ${ }^{1} \mathrm{O}_{2}$ lifetime determined from the non-linear curve fit of singlet oxygen phosphorescence signal at $1270 \mathrm{~nm}$. The error bars indicate the standard error of the non-linear fit and are within the symbol when not visible. The $R^{2}$ of the linear regression line is also indicated. D Representative Stern-Volmer plots used to determine

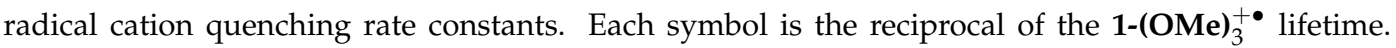
The error bars indicate the standard error of the non-linear fit. For easier comparison between experimental conditions, the ascorbic acid (AscA) concentrations are also expressed in $\mathrm{mg}_{\mathrm{C}} \mathrm{L}^{-1}$. 


\section{S8. Fenfuram degradation rates comparison in different experimental conditions}

Table S2. Summary of singlet oxygen-normalized fenfuram degradation rate constants obtained with model sensitizers. $k_{r x n}^{1} / k_{r x n}^{\mathrm{FFA}}$ was calculated from the measured pseudo-first-order degradation rate constants, and the errors were obtained from error propagation (more details in the main text, section "Reproducibility and error significance"). Excited state redox potentials $\left(E_{3 S^{*} / S^{\bullet-}}^{0 *}\right)$ are from McNeill and Canonica[2] or from Kalyanasundaram and Neumann-Spallartand[11] and are referred to SHE. Caffeic acid (CaffA) was present at a concentration of $10 \mu \mathrm{mol} \mathrm{L}-1$.

\begin{tabular}{lccc}
\hline Sensitizer (S) & $E_{3^{*} *^{*} / S^{\bullet-}}(\mathrm{V})$ & ${ }^{3} S^{*}$ quencher & $k_{r x n}^{1} / k_{r x n}^{\mathrm{FFA}}$ \\
\hline PN & 1.03 & - & $0.73 \pm 0.03$ \\
3MAP & 1.64 & - & $0.69 \pm 0.02$ \\
LC & 1.91 & - & $0.74 \pm 0.04$ \\
LC & 1.91 & CaffA & $0.73 \pm 0.02$ \\
Zn-por & 0.78 & - & $0.79 \pm 0.01$ \\
\hline
\end{tabular}




\section{S9. Degradation rate comparison among different furanilides (Figure 2B)}

\section{S9.1. Steady-state experiments}

Table S3. Summary of $k_{r x n}^{\mathrm{A}} / k_{r x n}^{\mathrm{FFA}}$ values determined via steady-state photolysis experiments using lumichrome (LC) and Swuannee River Fulvic Acid (SRFA) as the sensitizers. Errors are obtained by error propagation from experimental errors in the degradation rate constants (not shown) as detailed in the main text. ${ }^{a}$ In the LC-sensitized experiments, 1-OMe showed non-linear degradation kinetics. Specifically, we observed a fast degradation followed by a slower degradation (Figure S13). The rate constant reported here is referred to the slow-decaying portion of the curve.

\begin{tabular}{|c|c|c|}
\hline Compound & $\begin{array}{c}\mathrm{LC} \\
k_{r x n}^{\mathrm{A}} / k_{r x n}^{\mathrm{FFA}}\end{array}$ & $\begin{array}{c}\text { SRFA } \\
k_{r x n}^{\mathrm{A}} / k_{r x n}^{\mathrm{FFA}}\end{array}$ \\
\hline 0 & $0.064 \pm 0.003$ & $0.095 \pm 0.005$ \\
\hline 1 & $0.74 \pm 0.04$ & $0.71 \pm 0.03$ \\
\hline 2 & $2.87 \pm 0.16$ & $2.77 \pm 0.18$ \\
\hline 3 & $8.5 \pm 0.4$ & $5.8 \pm 0.2$ \\
\hline $1-\mathrm{CO}_{2} \mathrm{Me}$ & $0.616 \pm 0.013$ & $0.61 \pm 0.04$ \\
\hline 1 & $0.74 \pm 0.04$ & $0.71 \pm 0.03$ \\
\hline 1-Me & $0.99 \pm 0.03$ & $0.70 \pm 0.04$ \\
\hline 1-OMe & $0.99 \pm 0.03^{a}$ & $0.60 \pm 0.02$ \\
\hline $1-(\mathrm{OMe})_{3}$ & $1.30 \pm 0.02$ & $0.84 \pm 0.04$ \\
\hline $1-\mathrm{NMe}_{2}$ & $0.94 \pm 0.02$ & $0.93 \pm 0.05$ \\
\hline
\end{tabular}

Table S4. Summary of $\log \left(k_{r x n}^{\mathrm{A}} / k_{r x n}^{\mathrm{FFA}}\right)$ values calculated from the data in Table S3 and shown in Figure 2B (LC: filled circles; SRFA: filled triangles). The errors are obtained from propagation of the errors in Table S3.

\begin{tabular}{lcc}
\hline Compound & $\begin{array}{c}\mathrm{LC} \\
\log \left(k_{r x n}^{\mathrm{A}} / k_{r x n}^{\mathrm{FFA}}\right)\end{array}$ & $\begin{array}{c}\text { SRFA } \\
\log \left(k_{r x n}^{\mathrm{A}} / k_{r x n}^{\mathrm{FFA}}\right)\end{array}$ \\
\hline $\mathbf{0}$ & $-(1.19 \pm 0.02)$ & $-(1.02 \pm 0.02)$ \\
$\mathbf{1}$ & $-(0.13 \pm 0.03)$ & $-(0.15 \pm 0.02)$ \\
$\mathbf{2}$ & $0.46 \pm 0.03$ & $0.44 \pm 0.03$ \\
$\mathbf{3}$ & $0.93 \pm 0.02$ & $0.76 \pm 0.02$ \\
& & \\
$\mathbf{1 - C O} \mathbf{C O}_{2} \mathbf{M e}$ & $-(0.210 \pm 0.009)$ & $-(0.22 \pm 0.03)$ \\
$\mathbf{1}$ & $-(0.13 \pm 0.03)$ & $-(0.15 \pm 0.02)$ \\
$\mathbf{1 - M e}$ & $0.00 \pm 0.02$ & $-(0.16 \pm 0.02)$ \\
$\mathbf{1 - O M e}$ & $-(0.006 \pm 0.013)$ & $-(0.22 \pm 0.02)$ \\
$\mathbf{1 - ( O M e )})_{3}$ & $0.11 \pm 0.02$ & $-(0.08 \pm 0.02)$ \\
$\mathbf{1 - N M e} 2$ & $-(0.028 \pm 0.009)$ & $-(0.03 \pm 0.02)$ \\
\hline
\end{tabular}




\section{S9.2. Calculated values}

\section{Calculated singlet oxygen contribution (open squares)}

If singlet oxygen is the only reactive intermediate responsible for the degradation of A (thus, $\left.k_{3 S}^{\mathrm{A}}=0\right)$, the pseudo-first-order degradation rate constant $\left(k_{r x n}^{\mathrm{A}}\right)$ can be calculated according to equation S4.

$$
k_{r x n}^{\mathrm{A}}=k_{1 \mathrm{O} 2}^{\mathrm{A}}\left[{ }^{1} \mathrm{O}_{2}\right]_{s s},
$$

where $\left[{ }^{1} \mathrm{O}_{2}\right]_{s s}$ is the singlet oxygen steady-state concentration and $k_{1 \mathrm{O} 2}^{\mathrm{A}}$ is the bimolecular reaction rate constant of $\mathrm{A}$ with singlet oxygen. If physical quenching is negligible, $k_{1 \mathrm{O} 2}^{\mathrm{A}}$ is the bimolecular rate constant measured via time-resolved singlet oxygen phosphorescence (Table 1 , main text). The same relationship can be written for FFA, which is a pure singlet oxygen chemical quencher.[12] Thus, $\log \left(k_{r x n}^{\mathrm{A}} / k_{r x n}^{\mathrm{FFA}}\right)$ can be obtained directly from the bimolecular rate constants according to equation S5, where $k_{1 \mathrm{O} 2}^{\mathrm{FFA}}=1.00 \times 10^{8} \mathrm{M}^{-1} \mathrm{~s}^{-1}$ at $22^{\circ} \mathrm{C}$ [9].

$$
\log \left(\frac{k_{r x n}^{\mathrm{A}}}{k_{r x n}^{\mathrm{FFA}}}\right)=\log \left(\frac{k_{102}^{\mathrm{A}}}{k_{1 \mathrm{O} 2}^{\mathrm{FF}}}\right)
$$

\section{Calculated singlet oxygen + triplet CDOM contribution (open diamonds)}

If $\mathrm{A}$ is degraded via both singlet oxygen and triplet $\mathrm{CDOM}$, its pseudo-first-order rate constant $\left(k_{r x n}^{\mathrm{A}}\right)$ can be written as following.

$$
k_{r x n}^{\mathrm{A}}=k_{1 \mathrm{O} 2}\left[{ }^{1} \mathrm{O}_{2}\right]_{s s}+k_{3 \mathrm{CDOM}}^{\mathrm{A}}\left[{ }^{3} \mathrm{CDOM}^{*}\right]_{s s}
$$

where $k_{1 \mathrm{O} 2}^{\mathrm{A}}$ and $k_{1 \mathrm{O} 2}^{\mathrm{A}}$ are the bimolecular rate constants of $\mathrm{A}$ with singlet oxygen and ${ }^{3} \mathrm{CDOM}^{*}$, respectively. The theoretical $\left[{ }^{3} \mathrm{CDOM}^{*}\right]_{s s}$ can be expressed as a function of singlet oxygen concentration according to equation S3.[2]

$$
\left[{ }^{3} \mathrm{CDOM}^{*}\right]_{s s}=\frac{\left[{ }^{1} \mathrm{O}_{2}\right]_{s s}}{C f_{\Delta}}
$$

As a result, equation $\mathrm{S} 6$ can be rearranged as following, leading to equation S9 (equation 4 in the main text).

$$
k_{r x n}^{\mathrm{A}}=\left(k_{1 \mathrm{O} 2}+\frac{k_{3 \mathrm{CDOM}}^{\mathrm{A}}}{C f_{\Delta}}\right)\left[{ }^{1} \mathrm{O}_{2}\right]_{s s}
$$

If we assume that physical quenching is negligible for both pathways and that $3 \mathrm{MAP}$ is a good model for natural organic matter (i.e., $k_{3 \mathrm{ACDOM}}^{\mathrm{A}}=k_{33 \mathrm{MAP}}^{\mathrm{A}}$ ), then $k_{r x n}^{\mathrm{A}} / k_{r x n}^{\mathrm{FFA}}$ is again independent of $\left[{ }^{1} \mathrm{O}_{2}\right]_{s s}$. By combining equations $\mathrm{S} 4$ (for FFA) and S8, one gets to the following expression.

$$
\log \left(\frac{k_{r x n}^{\mathrm{A}}}{k_{r x n}^{\mathrm{FFA}}}\right)=\log \left(\frac{k_{1 \mathrm{O} 2}^{\mathrm{A}}+k_{33 \mathrm{MAP}}^{\mathrm{A}} / C f_{\Delta}}{k_{1 \mathrm{O} 2}^{\mathrm{FFA}}}\right)
$$

Unfortunately, $f_{\Delta}$ is not known for DOM. Therefore, we evaluated equation S9 for the two cases of $f_{\Delta}=0.5$ and 1. The constant $C$ was set to the value of SRFA at $35{ }^{\circ} \mathrm{C}$ (i.e., $C=0.64$; see Table S1), which was the temperature measured in the steady-state experiments. The value of $k_{1 \mathrm{O} 2}^{\mathrm{FF}}$ was set to $(1.00 \pm 0.01) \times 10^{8} \mathrm{M}^{-1} \mathrm{~s}^{-1}$ [9] and the other rate constants were from Table 1 (main text). The results are provided in Table S5.

In order to evaluate the effect of a variation in the different input variables, we performed a simple sensitivity analysis for the nine furanilides (Figure S5). The analysis revealed that errors in the input rate constants (see Table 1, main text) have a negligible effect on the dual-model output 
( $< \pm 4 \%$ variation). Replacing the value $C=0.64$ with the one calculated at $20^{\circ} \mathrm{C}(\mathrm{C}=0.85$; see Table $\mathrm{S} 1)$ lead to $\operatorname{lower} \log \left(k_{r x n}^{\mathrm{A}} / k_{r x n}^{\mathrm{FFA}}\right)$ values (median value: $\left.-8 \%\right)$. The largest effect was observed for the variable $f_{\Delta}$, which lead to an overestimation of $+17 \%$ to $+54 \%$ of the model output, depending on the individual compounds (median value: $+23 \%$ ).

Table S5. Calculated singlet oxygen and triplet contributions in the three scenarios of singlet oxygen reactivity only (equation S5, open squares in Figure 2B), and singlet oxygen and triplet CDOM reactivity (equation S9) with $f_{\Delta}=0.5$ (not shown in Figure $2 \mathrm{~B}$ ) and $f_{\Delta}=1$ (open diamonds in Figure $2 B)$. The parameter $C$ was fixed to the value of SRFA $(C=0.64)$. Errors were obtained from error propagation using the uncertainties in the rate constants; in this calculation, the errors in $f_{\Delta}$ and $C$ were assumed to be zero.

\begin{tabular}{lccc}
\hline Compound & $\begin{array}{c}{ }^{1} \mathrm{O}_{2} \\
\log \left(k_{r x n}^{\mathrm{A}} / k_{r x n}^{\mathrm{FFA}}\right)\end{array}$ & $\begin{array}{c}{ }^{1} \mathrm{O}_{2}+{ }^{3} \mathrm{CDOM}^{*}\left(f_{\Delta}=0.5\right) \\
\log \left(k_{r x n}^{\mathrm{A}} / k_{r x n}^{\mathrm{FFA}}\right)\end{array}$ & $\begin{array}{c}{ }^{1} \mathrm{O}_{2}+{ }^{3} \mathrm{CDOM}^{*}\left(f_{\Delta}=1\right) \\
\log \left(k_{r x n}^{\mathrm{A}} / k_{r x n}^{\mathrm{FFA}}\right)\end{array}$ \\
\hline $\mathbf{0}$ & $-(1.19 \pm 0.03)$ & $1.38 \pm 0.02$ & $1.08 \pm 0.04$ \\
$\mathbf{1}$ & $-(0.08 \pm 0.02)$ & $0.71 \pm 0.03$ & $0.48 \pm 0.04$ \\
$\mathbf{2}$ & $0.47 \pm 0.02$ & $0.95 \pm 0.02$ & $0.77 \pm 0.02$ \\
$\mathbf{3}$ & $0.53 \pm 0.03$ & $1.15 \pm 0.03$ & $0.94 \pm 0.04$ \\
& & & \\
$\mathbf{1 - C O} \mathbf{C O}_{2} \mathbf{M e}$ & $0.02 \pm 0.02$ & $0.49 \pm 0.04$ & $0.32 \pm 0.05$ \\
$\mathbf{1}$ & $-(0.08 \pm 0.02)$ & $0.71 \pm 0.03$ & $0.48 \pm 0.04$ \\
$\mathbf{1 - M e}$ & $-(0.14 \pm 0.05)$ & $0.71 \pm 0.05$ & $0.47 \pm 0.07$ \\
$\mathbf{1 - O M e}$ & $-(0.05 \pm 0.02)$ & $1.82 \pm 0.05$ & $1.53 \pm 0.09$ \\
$\mathbf{1 - ( O M e})_{3}$ & $-(0.13 \pm 0.03$ & $1.84 \pm 0.02$ & $1.55 \pm 0.03$ \\
$\mathbf{1 - N M e}$ & $0.56 \pm 0.02$ & $1.99 \pm 0.02$ & $1.70 \pm 0.04$ \\
\hline
\end{tabular}

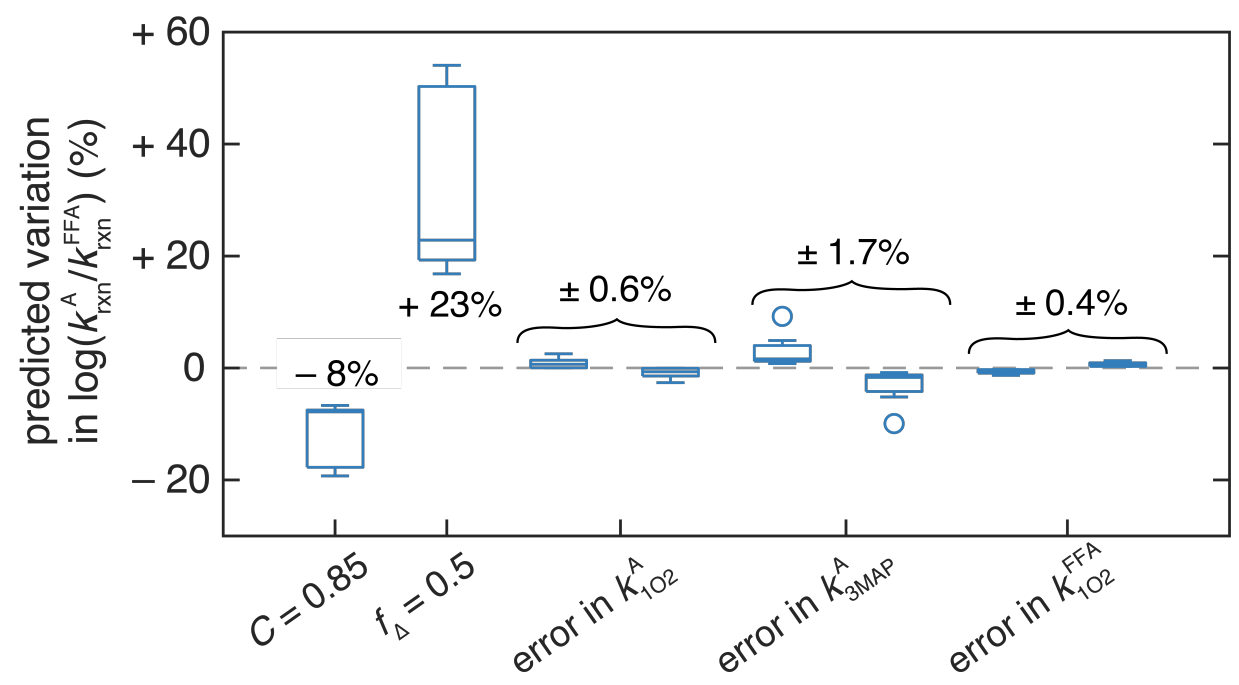

Figure S5. Effect of the variation of the various input parameters on the dual-reactivity model output calculated for the nine furanilides of this study. The $y$-axis indicate the percent variation in $\log \left(k_{r x n}^{\mathrm{A}} / k_{r x n}^{\mathrm{FFA}}\right.$ compared to the reference value calculated as in the third column of Table S5 $\left(C=0.64, f_{\Delta}=1\right)$. Each boxplot has $N=9$; the numbers indicate the median value of the boxplot. 


\section{S10. Hammett plot}

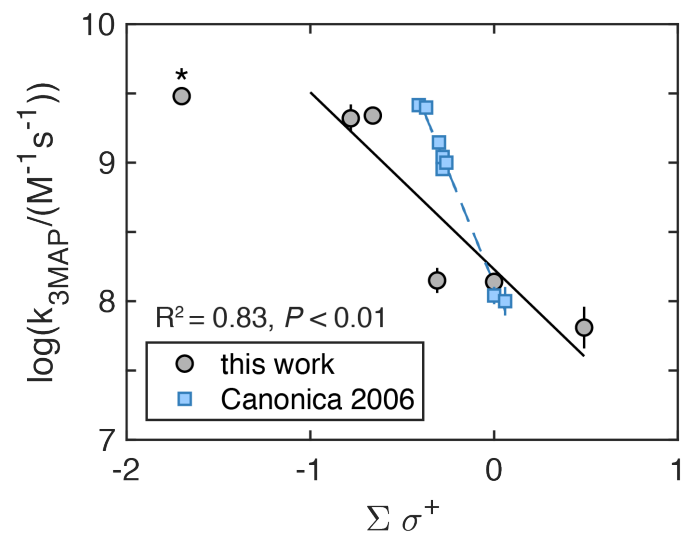

Figure S6. Hammett plot showing the bimolecular rate constants $k_{3 \mathrm{MAP}}^{\mathrm{A}}$ against the parameter $\Sigma\left(\sigma^{+}\right)=\sigma_{p}^{+}+\sigma_{m}$, which was calculated accodirng to Gerecke et al.[13] The graph also reports the results from Canonica et al. for phenylurea herbicides (blue squares).[14] The data reported here are limited to the amide series; the point indicated with an asterisk is excluded from the regression line, as it falls above the expected diffusion-limited rate constant for $3 \mathrm{MAP}$, i.e. $\approx 5 \times 10^{9} \mathrm{M}^{-1} \mathrm{~s}^{-1}$. 
S11. Supplementary transient absorption spectra
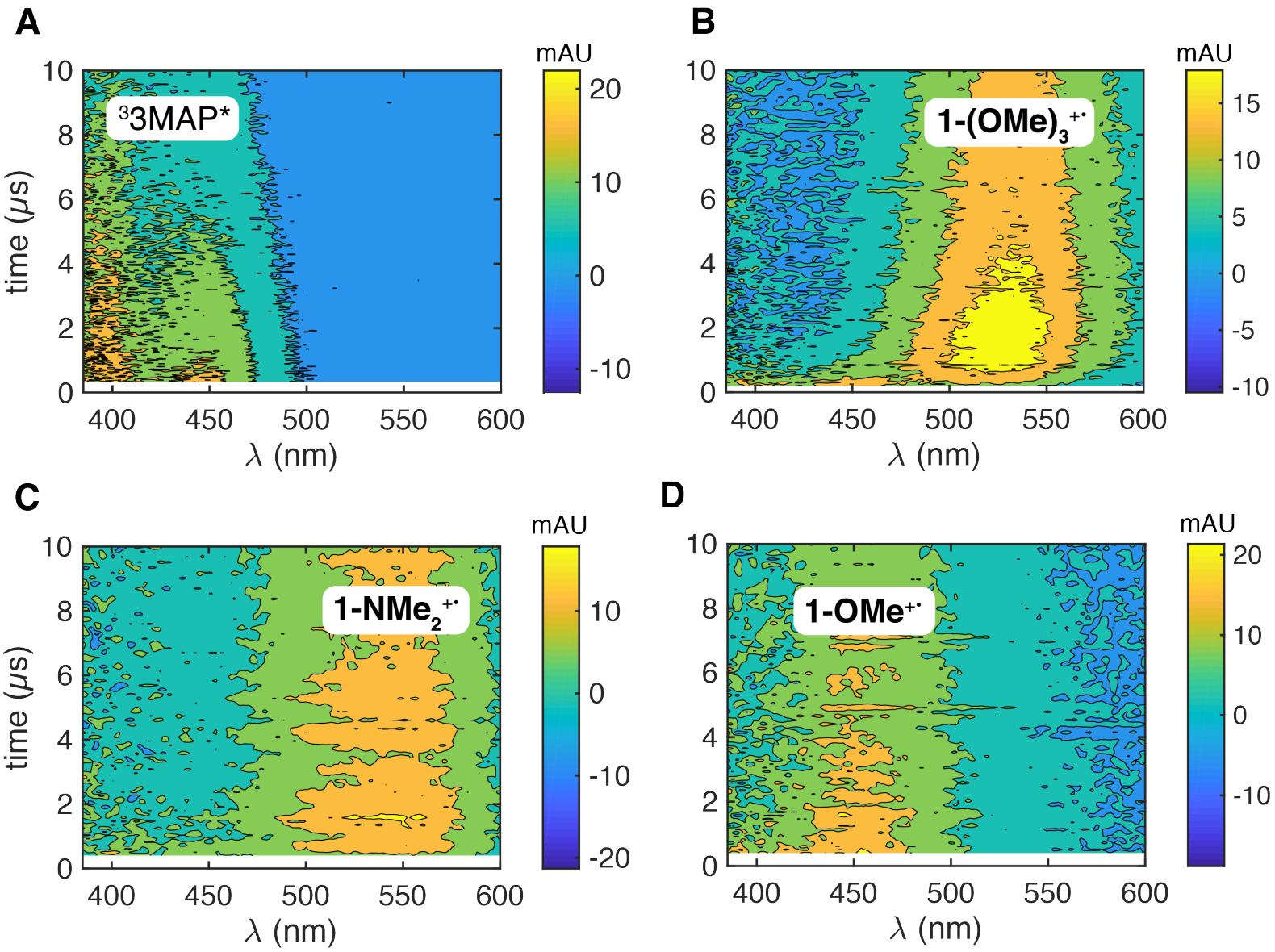

Figure S7. Transient absorption spectra of compounds showing an additional signal upon ${ }^{3} 3 \mathrm{MAP}^{*}$ quenching. A ${ }^{3} 3 \mathrm{MAP}^{*}$ transient absorption in $\mathrm{pH} 7$ phosphate buffer $\left([3 \mathrm{MAP}]=0.5 \mathrm{mmol} \mathrm{L}{ }^{-1}\right)$ upon excitation at $325 \mathrm{~nm}$. B Upon addition of 1-(OMe) $)_{3}$, a new signal appeared at $535 \mathrm{~nm}$, which was

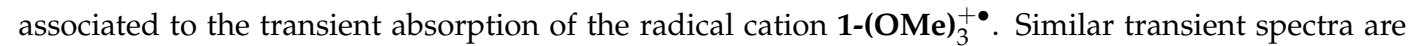
observed upon addition of 1-NMe $2(\mathbf{C}, 555 \mathrm{~nm})$ and $\mathbf{1 - O M e}(\mathbf{D}, 450 \mathrm{~nm})$. These spectra were collected in the presence of $0.5 \mathrm{mmol} \mathrm{L}^{-1} 3 \mathrm{MAP}+0.5 \mathrm{mmol} \mathrm{L}^{-1}$ furanilide, with $\lambda_{\text {exc }}=325 \mathrm{~nm}$. 
A

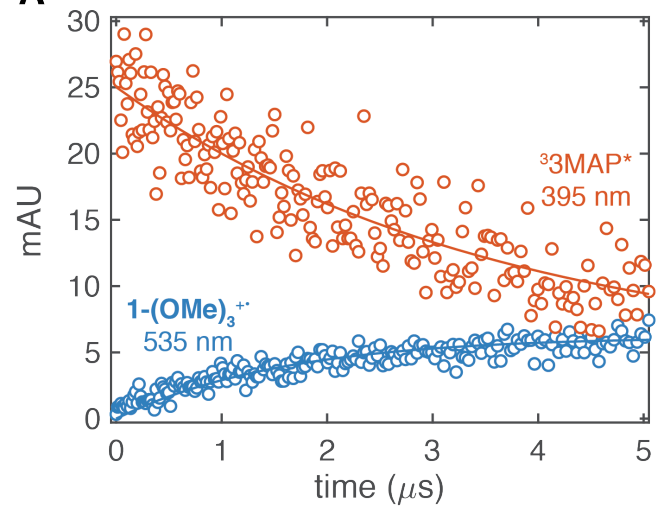

B

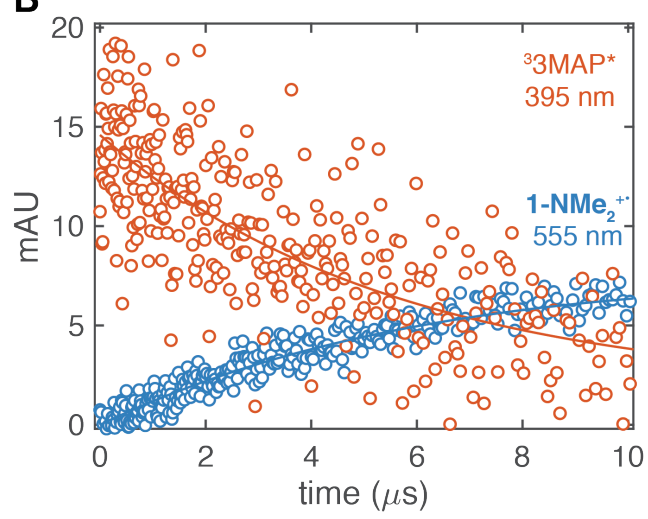

Figure S8. A Kinetics of ${ }^{3} 3 \mathrm{MAP} *$ decay $\left(395 \mathrm{~nm}\right.$, red, $\left.\tau_{\text {decay }}^{33 \mathrm{MAP}^{*}}=3.6 \pm 0.2 \mu \mathrm{s}\right)$ and 1-(OMe $)_{3}{ }^{+}$growth $\left(535 \mathrm{~nm}\right.$, blue, $\left.\tau_{\text {growth }}^{\mathbf{1 - ( \mathrm { OMe } _ { 3 }}}{ }^{{ }^{++}}=1.64 \pm 0.06 \mu \mathrm{s}\right)$ collected in the presence of $3 \mathrm{MAP}\left(0.5 \mathrm{mmol} \mathrm{L}{ }^{-1}\right)$ and 1-(OMe $)_{3}\left(0.1 \mathrm{mmol} \mathrm{L}^{-1}\right)$ in $\mathrm{pH} 7$ phosphate buffer. B Kinetics of ${ }^{3} 3 \mathrm{MAP}^{*}$ decay $(395 \mathrm{~nm}$, red, $\left.\tau_{\text {decay }}^{33 \mathrm{MAP}^{*}}=5.6 \pm 0.5 \mu \mathrm{s}\right)$ and $\mathbf{1 - \mathbf { N M e } _ { 2 }}{ }^{+\bullet}$ growth $\left(555 \mathrm{~nm}\right.$, blue, $\left.\tau_{\text {growth }}^{\mathbf{1 - \mathrm { NMe } ^ { * }}}=5.31 \pm 0.15 \mu \mathrm{s}\right)$ collected in the presence of $3 \mathrm{MAP}\left(0.5 \mathrm{mmol} \mathrm{L}^{-1}\right)$ and 1-NMe $2\left(25 \mu \mathrm{mol} \mathrm{L}^{-1}\right)$ in $\mathrm{pH} 7$ phosphate buffer.

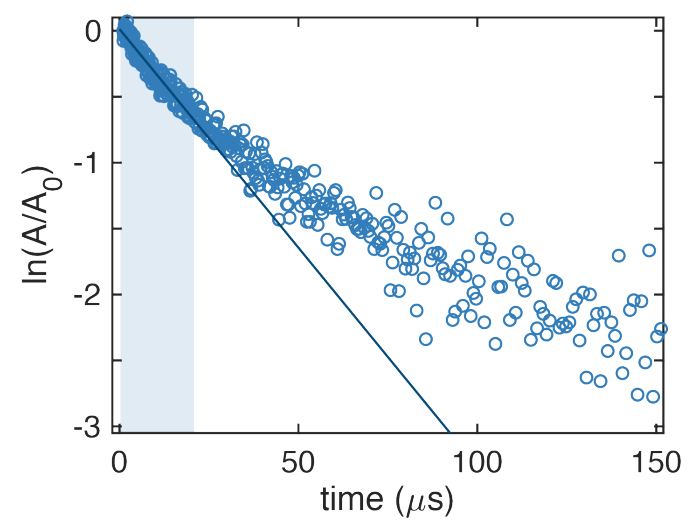

Figure S9. Radical cation $\left(\mathbf{1}-(\mathrm{OMe})_{3}{ }^{+}, 535 \mathrm{~nm}\right)$ decay kinetics collected in the presence of 3MAP

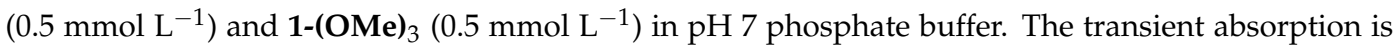
plotted in logarithmic scale in order to highlight the deviation from the pseudo-first-order behaviour observed $\approx 20 \mu$ s after the formation of the radical cation. The linear portion (shaded area) was used to obtain the antioxidant quenching bimolecular rate constants. 

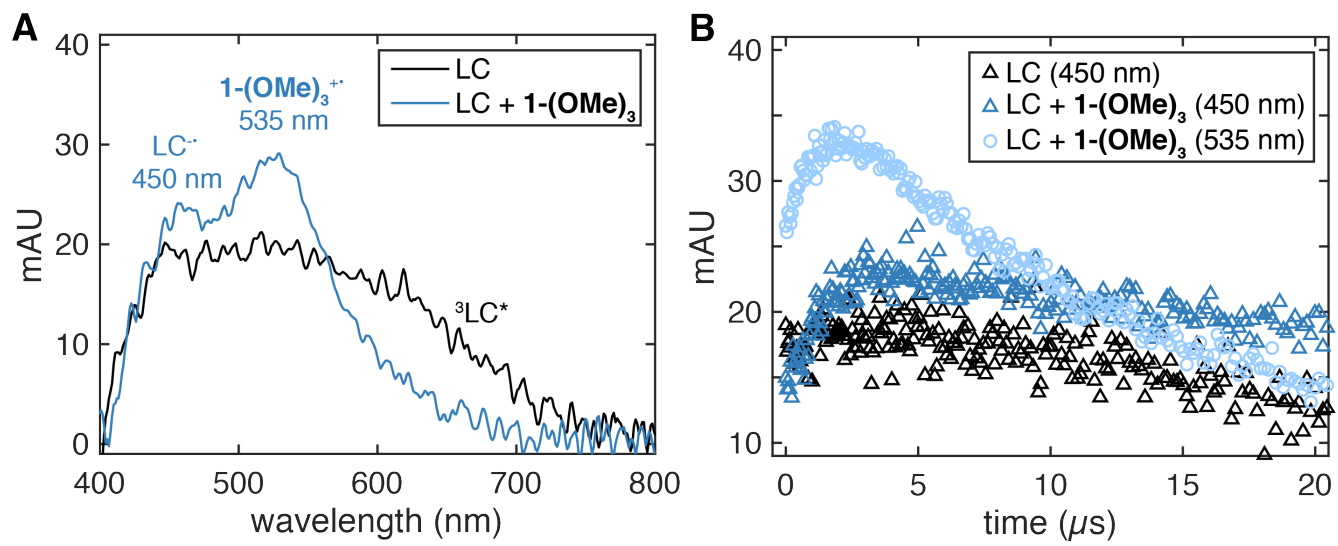

Figure S10. A Transient absorption (TA) spectra at $t=5 \mu$ s collected in the presence of lumichrome only (black) or lumichrome $+\mathbf{1 - ( O M e )})_{3}$ (blue). When only LC was present, a broad transient absorption appeared between 400 and $750 \mathrm{~nm}$, corresponding to the absorption of the triplet overlapped with the absorption of the lumichrome radical anion ( $\mathrm{LC}^{-\bullet}, 450 \mathrm{~nm}$ ).[15] Addition of 1-(OMe) ${ }_{3}$ quenched the ${ }^{3} \mathrm{LC}^{*}$ signal and resulted in the appearance of a narrower transient absorption band at $535 \mathrm{~nm}$, which was identified as the furanilide radical cation 1-(OMe) ${ }_{3}^{+\bullet}$. Furthermore, in the presence of $1-(\mathrm{OMe})_{3}$, the $\mathrm{LC}^{-\bullet}$ signal at $450 \mathrm{~nm}$ became a visible peak separated from the broad ${ }^{3} \mathrm{LC}^{*}$ band. These changes in the TA spectra provide a strong empirical evidence in support of the following process: $\left.{ }^{3} \mathrm{LC}^{*}+\mathbf{1 -}(\mathrm{OMe})_{3} \longrightarrow \mathrm{LC}^{-\bullet}+\mathbf{1 - ( O M e}\right)_{3}^{+\bullet}$ (i.e., reactive triplet quenching). B Growth-decay kinetics of $\mathrm{LC}^{-\bullet}(450 \mathrm{~nm} \text {, triangles) or } \mathbf{1 - ( O M e})_{3}^{+\bullet}(535 \mathrm{~nm}$, circles) referred to the TA spectra on the left (A). The plot clearly shows that the growing kinetics of the LC radical anion are influenced by the presence of the furanilide. Upon addition of $\mathbf{1 - ( O M e})_{3}$, the $\mathrm{LC}^{-\bullet}$ growth kinetics changed, mirroring the growth kinetics of the radical cation. This result further suggests that the two species are products of the same reaction. These spectra were collected in the presence of LC $\left.\left(0.1 \mathrm{mmol} \mathrm{L}^{-1}\right), \mathbf{1 - ( O M e}\right)_{3}$ $(0.3 \mathrm{mmol} \mathrm{L}-1)$ in $50 \% \mathrm{pH} 6$ buffer $+50 \%$ acetonitrile, with $\lambda_{\text {exc }}=360 \mathrm{~nm}$. 


\section{S12. Antioxidant quenching experiments}

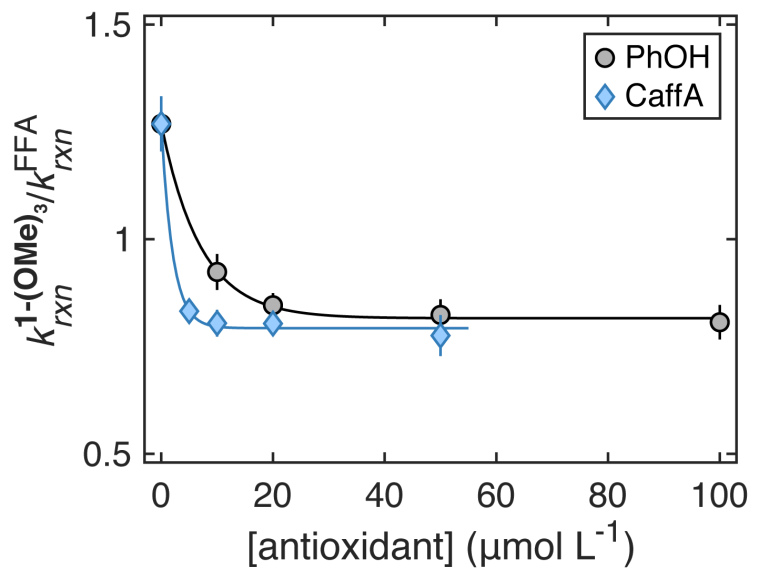

Figure S11. Steady-state experiments using phenol ( $\mathrm{PhOH}$, black filled circles) or caffeic acid (CaffA, blue filled diamonds) as the antioxidants and $\mathrm{PN}$ as the sensitizer. The data represent average of at least duplicate experiments, and the error bars are obtained from error propagation using the errors in the individual rate constants (within the symbols when not visible). The data were fitted with an exponential decay to obtain the $k_{r x n}^{\mathbf{1 - ( O M e})_{3}} / k_{r x n}^{\mathrm{FFA}}$ value at the plateau. The fit provided $k_{r x n}^{\mathbf{1 - ( O M e})_{3}} / k_{r x n}^{\mathrm{FFA}}=$ $0.82 \pm 0.01$ for $\mathrm{PhOH}\left(R^{2}=0.999, P<0.01, N=5\right)$ and $0.77 \pm 0.01$ for CaffA $\left(R^{2}=0.998, P<\right.$ $0.01, N=5)$. 


\section{S13. Details of the calculated FFA-normalized 1-(OMe $)_{3}$ degradation rate constants}

\section{Perinaphthenone}

Using the experimental $\left[{ }^{1} \mathrm{O}_{2}\right]_{S S}^{\mathrm{FFA}} /\left[{ }^{3} \mathrm{~S}^{*}\right]_{S \mathcal{S}}^{\mathrm{TMP}}$ value, we estimated the expected FFA-normalized rate constant according to equation S10, where $\left(C f_{\Delta}\right)_{\exp }=\left[{ }^{1} \mathrm{O}_{2}\right]_{S S}^{\mathrm{FFA}} /\left[{ }^{3} \mathrm{~S}^{*}\right]_{S S}^{\mathrm{TMP}}$ (equation S3).

$$
\frac{k_{r x n}^{1-(\mathrm{OMe}) 3}}{k_{r x n}^{\mathrm{FFA}}}=\frac{k_{1 \mathrm{O} 2}^{1-(\mathrm{OMe}) 3}+\frac{k_{33 \mathrm{MAP}}^{1-(\mathrm{OM}) 3}}{\left(\mathrm{C} f_{\Delta}\right)_{\text {exp }}}}{k_{1 \mathrm{O} 2}^{\mathrm{FA}}}
$$

\section{Lumichrome}

For lumichrome, we obtained an experimental ratio of $\left[{ }^{1} \mathrm{O}_{2}\right]_{S S}^{\mathrm{FFA}} /\left[{ }^{3} \mathrm{~S}^{*}\right]_{S \mathcal{S}}^{\mathrm{TMP}}=2.2 \pm 0.5$, which is slightly higher than the theoretical value $\left(C=1.48\right.$ at $25^{\circ} \mathrm{C}$, Table $\left.\mathrm{S} 1\right)$. We have two possible explanations for this result.

First, the TMP-based triplet concentration was obtained using the TMP quenching rate constant for riboflavin and not for lumichrome $\left(k_{3 \mathrm{~S}}^{\mathrm{TMP}}=2.2 \times 10^{9} \mathrm{~L} \mathrm{~mol}^{-1} \mathrm{~s}^{-1}\right)$ [8]. Even though these molecules have a very similar structure (lumichrome is a riboflavine photodegradation product[16]), their TMP quenching rate constants can still be slightly different. Second, $C$ was calculated using an oxygen quenching rate constant measured at $\mathrm{pH}$ 6. In water, $\mathrm{LC}$ is present in different ionization states and tautomeric forms depending on the solution $\mathrm{pH}$.[17] Therefore, variations in quenching rate constant as a function of $\mathrm{pH}$ can be anticipated. In addition, some variations on the $f_{\Delta}$ values can be found in the literature. Sikorski et al. measured $f_{\Delta}=1$ at $\mathrm{pH} 6$, but in a later publication they estimated it to be in the range $0.6-1 .[10,18]$ A $f_{\Delta}$ below unit would decrease the theoretical $\left[{ }^{1} \mathrm{O}_{2}\right]_{s s} /\left[{ }^{3} \mathrm{~S}^{*}\right]_{s s}$ ratio, increasing the discrepancy between measured and calculated values. In conclusion, at the current state of the knowledge we cannot say if the mismatch between the calculated and the experimental value is due to a real effect or if it only an artifact related to the uncertainties in the rate constants.

Using the experimental $\left[{ }^{1} \mathrm{O}_{2}\right]_{S S}^{\mathrm{FFA}} /\left[{ }^{3} \mathrm{~S}^{*}\right]_{S S}^{\mathrm{TMP}}$ value, we estimated an expected FFA-normalized rate constant of 10.8 (equation S10). The comparison between calculated and experimental values is presented in Figure S12.

\section{Suwannee River Fulvic Acid}

Similarly to the previous two cases, the expected FFA-normalized rate constant for the SRFA-sensitized experiments was obtained according to equation S10.

In addition, we estimated the effect of a 4-fold decrease in the bimolecular triplet rate constant on the calculated $k_{r x n}^{1-(\mathrm{OMe}) 3} / k_{r x n}^{\mathrm{FFA}}$ value. The reduction factor was estimated based on the data available for TMP. Indeed, Eirckson, Moor et al. measured TMP quenching rate constants of $5.4 \times 10^{8} \mathrm{~L} \mathrm{~mol}^{-1} \mathrm{~s}^{-1}$ and $2.2 \times 10^{9} \mathrm{~L} \mathrm{~mol}^{-1} \mathrm{~s}^{-1}$ for SRFA and PN, respectively,[8]. Thus, for SRFA the rate constant was 4.1 times smaller than for PN. The FFA-normalized rate constant was then obtained accorging to equation S11.

$$
\frac{k_{r x n}^{1-(\mathrm{OMe}) 3}}{k_{r x n}^{\mathrm{FFA}}}=\frac{k_{1 \mathrm{O} 2}^{1-(\mathrm{OMe}) 3}+\frac{k_{33 \mathrm{MAP}}^{1-(\mathrm{OM}) 3} / 4}{\left(C f_{\Delta}\right)_{\exp }}}{k_{1 \mathrm{O} 2}^{\mathrm{FA}}}
$$

The comparison between calculated and experimental values is presented in Figure S12. 


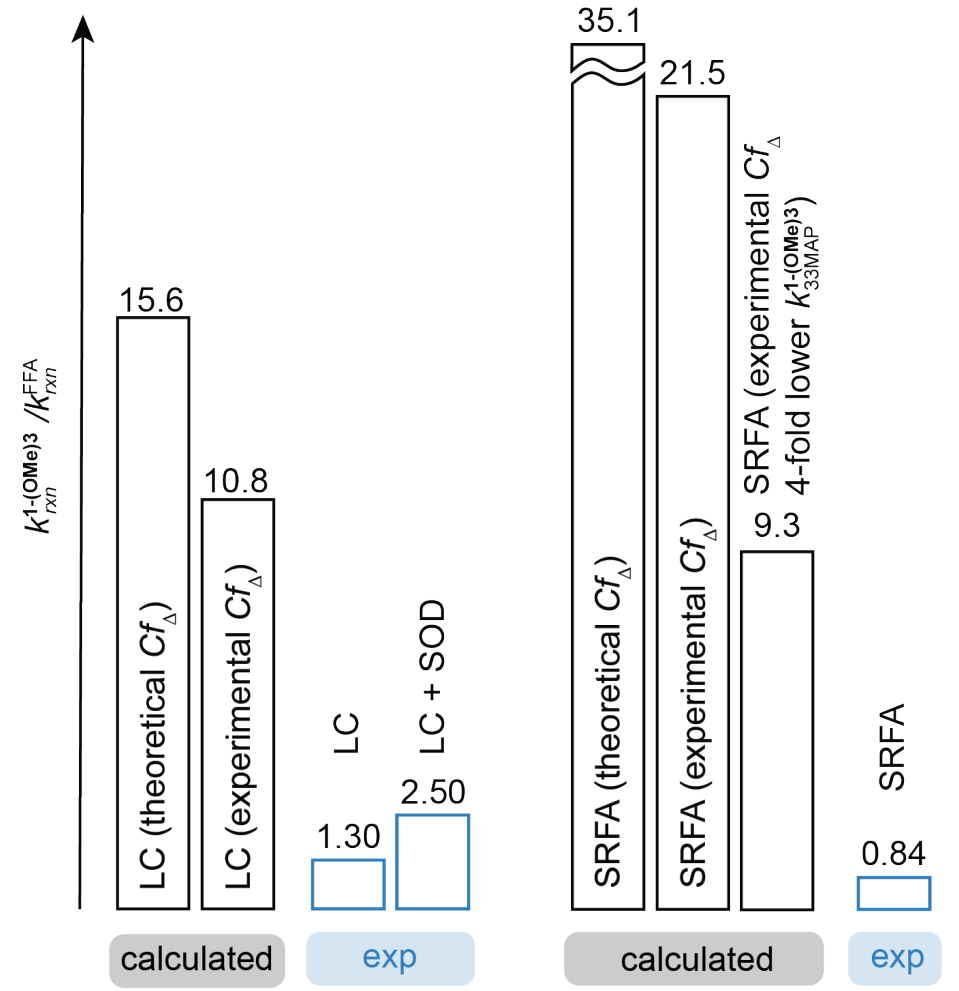

Figure S12. Summary of calculated and measured $k_{r x n}^{1-(\mathrm{OMe}) 3} / k_{r x n}^{\mathrm{FFA}}$ valued for the LC- and SRFA-sensitized degradation of 1-(OMe) $)_{3}$. 


\section{S14. Supplementary data on the indirect degradation of 1-OMe}

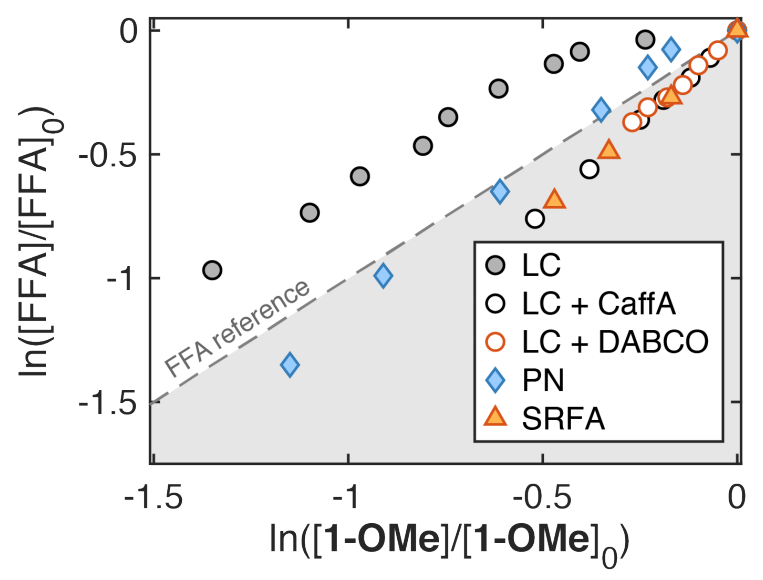

Figure S13. Experiments investigating the steady-state degradation kinetics of 1-OMe. Similarly to Figure 3A, the results are plotted as $\ln \left([\mathrm{FFA}] /[\mathrm{FFA}]_{0}\right)$ vs $\ln \left([\mathbf{1 - O M e}] /[\mathbf{1 - O M e}]_{0}\right)$. The data points are average of duplicate experiments. The error bars are omitted for clarity as they fall within the symbols. The grey dotted line represents the degradation kinetics of FFA in the various experimental conditions, meaning that data in the grey area have $k_{r x n}^{1-O M e} / k_{r x n}^{\mathrm{FFA}}<1$, while data in the white area have $k_{r x n}^{1-O M e} / k_{r x n}^{\mathrm{FFA}}>1$. In the presence of SRFA (filled orange triangles), 1-OMe showed well-behaved pseudo-first-order kinetics, with $k_{r x n}^{1-O M e} / k_{r x n}^{\mathrm{FFA}}=0.60 \pm 0.02$. Similarly, in the presence of LC and either a singlet oxygen quencher (DABCO, open orange circles) or an antioxidant (CaffA, open black circles), 1-OMe degradation was linear and reproduced well the results of the SRFA-sensitized experiment. On the other hand, in the presence of model sensitizers only, either LC (filled black circles) or PN (filled blue diamonds), 1-OMe showed a fast degradation followed by a slower decay that had $k_{r x n}^{1-\mathrm{OMe}} / k_{r x n}^{\mathrm{FFA}}=0.74$ and 0.99 for PN and LC, respectively. Furthermore, the first fast decay seemed to be more pronounced in the case of LC, thus in the presence of a sensitizer with higher excited state redox potential.[2] Even though we did not investigate further this phenomenon, the bimodal kinetics appeared to be associated with the triplet reactivity. Similar kinetics were also reported in the direct photolysis of tylosin and nitrofuran antibiotics.[19,20] In these cases, the non-linear kinetics were justified with the presence of a fast photoisomerization equilibrium competing with the degradation process. 


\section{S15. Summary of the variables used in the equations}

Table S6. Summary of variables used in the equations in the main text and in the Supplementary Information. The letter in the apex $\mathrm{A}$ denotes a generic molecular species (i.e., $\mathrm{A}=\mathrm{FFA}, \mathrm{TMP}$, 1-(OMe) $\left.)_{3}, 1-(\mathrm{OMe})_{3}^{+}, \ldots\right)$.

\begin{tabular}{|c|c|c|}
\hline Variable & Unit & Description \\
\hline $\begin{array}{l}k_{r x n}^{\mathrm{A}} \\
k_{r x n}^{\mathrm{A}} / k_{r x n}^{\mathrm{FFA}} \\
k_{d}^{\Delta}\end{array}$ & $\begin{array}{c}\mathrm{s}^{-1} \\
{[-]} \\
\mathrm{s}^{-1}\end{array}$ & $\begin{array}{l}\text { Unimolecular degradation rate constant of } \mathrm{A} \\
\text { FFA-normalized unimolecular degradation rate constant of A } \\
\left.{ }^{1} \mathrm{O}_{2} \text { deactivation rate constant to } \mathrm{O}_{2} \text { (eq.s } 4, \mathrm{~S} 1, \mathrm{~S} 2\right)\end{array}$ \\
\hline $\begin{array}{l}k_{1 \mathrm{O} 2}^{\mathrm{A}} \\
k_{3 \mathrm{~S}}^{\mathrm{A}}\left(k_{3 \mathrm{MAP}}^{\mathrm{A}}\right) \\
k_{\mathrm{AO}}^{\mathrm{A}} \\
k_{\mathrm{O} 2}\end{array}$ & $\begin{array}{l}\mathrm{L} \mathrm{mol}^{-1} \mathrm{~s}^{-1} \\
\mathrm{~L} \mathrm{~mol} \mathrm{~s}^{-1} \\
\mathrm{~L} \mathrm{~mol} \mathrm{~mol}^{-1} \\
\mathrm{~L} \mathrm{~mol} \mathrm{mos}^{-1}\end{array}$ & $\begin{array}{l}\text { Bimolecular quenching rate constant of }{ }^{1} \mathrm{O}_{2} \text { with } \mathrm{A} \\
\text { Bimolecular quenching rate constant of }{ }^{3} \mathrm{~S}^{*}\left({ }^{3} 3 \mathrm{MAP}^{*}\right) \text { with } \mathrm{A} \\
\text { Bimolecular quenching rate constant of an antioxidant }(\mathrm{AO}) \text { with } \mathrm{A} \\
\left.\text { Bimolecular quenching rate constant of }{ }^{3} \mathrm{~S}^{*} \text { with } \mathrm{O}_{2} \text { (eq.s } 4, \mathrm{~S} 1, \mathrm{~S} 2\right)\end{array}$ \\
\hline $\begin{array}{l}C \\
f_{\Delta}\end{array}$ & $\begin{array}{l}{[-]} \\
{[-]}\end{array}$ & $\begin{array}{l}\text { See eq.s } 4 \text { and } \mathrm{S} 2 \\
\text { Fraction of }{ }^{3} \mathrm{~S}^{*} \text { quenching events that lead to }{ }^{1} \mathrm{O}_{2} \text { production } \\
\text { (eq.s } 3, \mathrm{~S} 3)\end{array}$ \\
\hline
\end{tabular}

\section{Bibliography}

1. Pelltier, G.; Bechara, W. S.; Charette, A. B. Journal of the American Chemical Society 2010, 132, 12817-12819.

2. McNeill, K.; Canonica, S. Environmental science: Processes E Impacts 2016, 18, 1381-1399.

3. Latch, D. E. In Surface Water Photochemistry; Calza, P., Vione, D., Eds.; Comprehensive Series in Photochemical Photobiological Sciences; The Royal Society of Chemistry, Chapter The Role of Singlet Oxygen in Surface Water Photochemistry.

4. Lundeen, R. A.; Janssen, E. M.-L.; Chu, C.; McNeill, K. Chimia 2014, 68, 812-817.

5. Davis, C. A.; Erickson, P. R.; McNeill, K.; Janssen, E. M.-L. Environmental Science: Processes E Impacts 2017, 19, 656-665.

6. Chu, C.; Stamatelatos, D.; McNeill, K. Environmental Science: Processes E Impacts 2017, 19, 1518-1527.

7. Remucal, C. K. Environmental Science: Processes \& Impacts 2014, 16, 628-653.

8. Erickson, P. R.; Moor, K. J.; Werner, J. J.; Latch, D. E.; Arnold, W. A.; McNeill, K. Environmental Science $\mathcal{E}$ Technology 2018, 52, 9170-9178.

9. Appiani, E.; Ossola, R.; Latch, D. E.; Erickson, P. R.; McNeill, K. Environmental Science: Processes E Impacts 2017, 19, 506-516.

10. Sikorski, M.; Sikorska, E.; Koziolowa, A.; Gonzalez Moreno, R.; Bouderlande, J. L.; Steer, R. P.; Wilkinson, F. Journal of Photochemistry and Photobiology B: Biology 2001, 60, 114-119.

11. Kalyanasundaram, K.; Neumann-Spallart, M. The Journal of Physical Chemistry 1982, 86, 5163-5169.

12. Braun, A. M.; Daha, H.; Gassmann, E.; Gerothanassis, I.; Jakob, L. Journal of Photochemistry and Photobiology 1999, 70, 169-173.

13. Gerecke, A. K.; S., C.; Müller, S. R.; Schärer, M.; R., S. Environmental Science E Technology 2001, 19, $3915-3923$.

14. Canonica, S.; Hellrung, B.; Müller, P.; Wirz, J. Environmental Science E Technology 2006, 21, 6636-6641.

15. Porcal, G.; Bertolotti, S. G.; Previtali, C. M.; Encinas, M. V. Physical Chemistry Chemical Physics 2003, 19, $4123-4128$.

16. Remucal, C. K.; McNeill, K. Environmental Science E Technology 2011, 42, 5230-5237.

17. Tyagi, A.; Penkofer, A. Photochemistry and Photobiology 2011, 87, 524-533.

18. Sikorska, E.; Sikorski, M.; Steer, R. P.; Wilkinson, F.; Worrall, D. R. Journal of the Chemical Society, Faraday Transactions 1998, 94, 2347-2353.

19. Werner, J. .; Chintapalli, M.; Lundeen, R. A.; Wammer, K. H.; Arnold, W. A.; Mcneill, K. Journal of Agricultural and Food Chemistry 2007, 55, 7062-7068. 
20. Edhlund, B. L.; Arnold, W. A.; McNeill, K. Environmental Science E Technology 2006, 40, 5422-5427. 